\title{
THE EFFECTIVENESS OF \\ AGROBUSINESS TECHNICAL TRAINING AND EDUCATION MODEL FOR THE FIELD AGRICULTURAL EXTENSION OFFICERS
}

\author{
Kristiyo Sumarwono \\ Badan Diklat Provinsi Jawa Tengah \\ kristiyo_s@yahoo.com \\ Sukardi \\ Faculty of Engineering Universitas Negeri Yogyakarta \\ Soenarto \\ Faculty of Engineering Universitas Negeri Yogyakarta \\ soenarto@uny.ac.id
}

\begin{abstract}
The study was to: (1) find the most effective agrobusiness technical training and education model for the Field Agricultural Extension Officers to be implemented; and (2) to identify the knowledge level, the highest agrobusiness skills and the strongest self-confidence that might be achieved by the participants through the implemented training and education patterns. The study was conducted by means of experiment method with the regular pattern of training and education program as the control and the mentoring pattern of training and education program as the treatment. The three patterns of training and education programs served as the independent variables while the knowledge, the skills and the self-confidence served as the dependent variables. The study was conducted in three locations namely: the Institution of Agricultural Human Resources Development in the Province of Yogyakarta Special Region (Balai Pengembangan Sumber Daya Manusia Pertanian Daerah Istimewa Yogyakarta - BPSMP DIY); the Institution of Agricultural Human Resources Empowerment (Balai Pemberdayaan Sumber Daya Manusia Pertanian - BPSDMTAN Soropadan Temanggung Provinsi Jawa Tengah) in Soropadan, Temanggung, the Province of Central Java; and the Institution of Training and Education in Semarang, the Province of Central Java (Badan Pendidikan dan Pelatihan Semarang Provinsi Jawa Tengah). The study was conducted to all of the participants who attended the agrobusiness technical training and education program and, therefore, all of the participants became the subjects of the study. The study was conducted from October 2013 until March 2014. The results of the study showed that: (1) there had not been any significant difference on the knowledge and the skills of the participants who attended the regular pattern in training and education programs and those who attended the mentoring pattern in training and education programs; (2) the regular pattern in training and education programs and the mentoring pattern in training and education programs had significant difference on the field agricultural extension officers' self-confidence ( $t$ count $=-2.28 ; p=0.03$ ) and ( $t$ count $=-2.41 ; p=0.02)$; and (3) the mentoring pattern in training and education programs showed very significant difference on the agrobusiness skills $(t$ count $=-4.94 ; p=0.00$ ). The mentoring pattern in training and education programs showed significant changes in improving the field agricultural extension officers' skills and confidence for about $9.43 \%$ and $7.75 \%$ respectively in implementing the agrobusiness activities compared to the other patterns of training and education programs.
\end{abstract}

Keyword: knowledge, skills, self-confidence, agrobusiness, internship 


\section{INTRODUCTION}

The agricultural development that has been implemented nowadays have 5 priorities that should be achieved. In relation to the statement, the domestic agricultural selfsufficiency and sovereignity have been the first or the top priority that should be achieved at least for the next three years. Rice, soyabean and corn have been the commodities which productions will be increased in order to meet the domestic food demands and to decrease the number of import. The efforts for supporting the agricultural self-sufficiency and sovereignity will be conducted under the following five workplans: (1) improving the irrigation channels; (2) improving the distribution system of seeds and fertilizers; (3) providing agricultural tools and machineries especially the tractors; (4) ensuring the marketing activities; and (5) empowering the Field Agricultural Extension Officers. The policy of pursuing the top priority has been written in the Ministry of Agriculture 20152019 Working Plans.

The agricultural activities nowadays have been left behind by the people especially the young generation. As a result, there has been a scarcity of employment in multipler agricultural centers such as the ones in the Province of Central Java and the Province of East Java and the case will be worse when it comes to both the planting season and the harvest. The classical reason is that to work in the agricultural domain will only result in the low daily-base income and the low daily-base income will be totally spent in days. Another reason is that there has been increasing cases of land-switching. In addition, for the young people to work in the agricultural domain has been less prospective and less interesting. In other words, the young people show less interest in studying the agricultural domain.

The competent field agricultural extension officers in the agrobusiness domain should become a certainty. Most of the farmers' products have not been well marketed in the big harvest. The farmers have not been able to market their abundant agricultural products under the normal price; as a result, they have quite big loss. For example, the price of rice grain among the farmers is Rp4,250.00/kg GKG. The price has not met the average production cost that the farmers spend namely Rp6,000.00. Therefore, the knowledge and the experience in the agrobusiness domain that the field agricultural extension officers have is heavily demanded by the farmers especially in overcoming the recurrent problems namely the marketing activities.

The prosperity improvement brings a consequence to the management of agricultural human resources development. The consequence of this policy is that all of the agricultural training and education programs should be directed and should be focused to the achievement of agricultural development main target. The efforts of achieving the agricultural self-sufficiency and sovereignity should be pursued by a program of contingency fund that costs $\mathrm{Rp} 1,300,000,000,000.00$ and the fund should be allocated to 12 provinces in order to accelerate the rice self-sufficiency. The target of rice self-sufficiency is 73.40 tons of dried milled rice (Gabah Kering Giling or GKG) in 2015 (Kementerian Pertanian, 2014, p. 155).

The training and education program for the field farming extension officers is implemented by the government training and education institutions under the Ministry of Agriculture, the Provincial and the County/ Regional Governments. These institutions are known as the Unit of Training and Education Program Technical Implementation and these institutions have been widely spread throughout the Republic of Indonesia. The training and education programs have been the agriculture technological transfer in the form of study results to all of the farmers and the field farming extension officers.

The field farming extension officers are trained in the Institutions of Training and Education by the instructors for several days in order to master the agricultural technologies or the agricultural programs. Then, their mastery of agricultural technologies and programs should be disseminated widely to the farmers. The training programs given by the instructors to the field farming extension officers should meet the requirements that have been written in the Government Regulation Number 101/2000 regarding the Training and Education Programs for the Government Apparatus. In the government regulation, it has been mentioned that the training and education programs for the civil 
servants are the rights and the duties both before and during the implementation of the civil servants' tasks (Badan Pendidikan dan Latihan Pertanian, 1993, p. 15).

\section{METHOD}

The study regarding the Effectiveness of Agrobusiness Technical Training and Education Program Model for the Field Farming Extension Officers was implemented in: the Institution of Training and Education for the Capitol of Semarang, the Province of Central Java; the Institution of Agricultural Human Resources Empowerment for the Region of Temanggung, the Province of Central Java; and the Institution of Agricultural Human Resources Development for the Capitol of Yogyakartam the Province of Yogyakarta Special Region. The research activities were conducted from October $1^{\text {st }}, 2013$ until March $31^{\text {st }}, 2014$. The population of the study was all of the stapple-food agrobusiness technical training and education program participants under the 2013/2014 that had been implemented by the Regional Institution of Training and Education (under the Regional Government) and the number of the population was 90 people. Based on the number, the whole population had been selected as the subjects.

In order to attain the necessary data for answering the proposed problem formulations, the researcher gathered the necessary data by means of the instrument that had been prepared before. The instrument was in the form of questions for the category of participants' knowledge level and within these questions the participants were just demanded to provide their answer by selecting the correct one from the four available options. Then the daya type, the data gathering method, the data gathering period and the instrument were designed in the following table within the next section.

The study was a quasi-experimental research; the design was selected due to the impossible condition in controlling or in manipulating all of the relevant variables. In the experimental design, the internship pattern became the treatment group in comparison to the regular pattern as the control group. In the practice,there were three pre-test sessions and three post-test sessions.
The population of the study was all of the Field Farming Extension Officers namely the participants of agrobusiness technical training and education programs. The number of the participants was 90 people and they were from three different sites of training and education programs in the Province of Central Java and the Province of Yogyakarta Special Region.

In order to identify the most effective agrobusiness training and education model for the Field Farming Extension Officers, an experimental study would be conducted with the following treatment:

$\mathrm{X}_{0}=$ The class of regular pattern in agrobusiness training and education program would serve as the control group.

$\mathrm{X}_{1}=$ The class of regular pattern in agrobusiness training and education program would be conducted by implementing the mentoring pattern.

$\mathrm{X}_{2}=$ The class of regular pattern in agrobusiness training and education program would be conducted by implementing the internship pattern.

The design that the researcher employed referred to a book entitled Research Methods in Education: An Introduction by William Wiersma, namely the Pretest-posttest, Nonequivalent Control Group Design with two experimental groups and one control group (Wiersma, 1995, p. 144).

The data analysis was conducted by performing a differentiation test toward the total score of the participants' agrobusiness concept understanding, agrobusiness skill and self-confidence before and after attending the training and education programs. The differentiation test was performed by using the ttest pair sample statistik technique. The differentiation test was conducted toward the cummulative score of all indicators in the dependent variables.

The data analysis was performed by means of SPSS (Statistical Program for Social Science) for Windows version 21.0 software. In the study, the researcher examined the influence of independent variable (the regular pattern, the mentoring pattern and the internship pattern) in the agrobusiness training and education programs toward the three independent variables (the agrobusiness concept 
mastery, the agrobusiness skills and the participants' self-confidence). The influence of each independent variable toward the three dependent variable would appear in two versions. The first version would be generated by the multivariate tests while the second version would be generated by the between-subject effect tests. The multivariate tests would display the influence of each independent variables to all of the dependent variables communally. On the other hand, the between-subject effect tests would display the influence of each independent variables to all of the dependent variables individually. The multivariate tests would be conducted to the significance values from the F-statistic, Pillai's Trace, Wilks' Lambda, Hotelling's Trace, dan Roy's Largest Root scores. Then, for the hypothesis test the researcher would implement the F-test by means of Manova with the assistance of SPSS 21.0 for Windows.

\section{RESULTS AND DISCUSSIONS}

The analysis prerequisite test that should be conducted to the parametric statistical test was the t-test and the Analysis of Variance (Anova). Then, the analysis prerequisite test that should be conducted to the Analysis of Variance (Anova) was the distribution normality test and the variant homogeneity test. The normality test was intended to view whether the research variables had normal data distribution or not. The Kolmogorov-Smirnov statistic analysis technique was implemented in order to test whether the research variables had normal distribution or not if the Kolmogorov-Smirnov significance values was bigger than 0.05; in other words, it might be concluded that the research variables had normal distribution. The results of normality test would be summarized in the following Table 1.

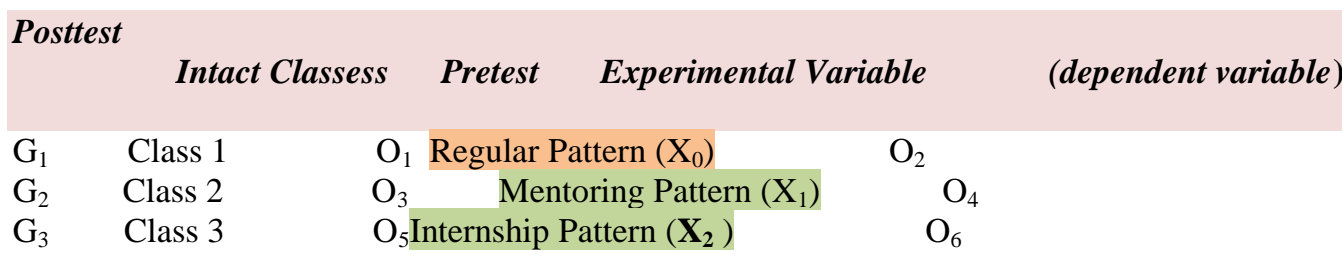

Figure 1. Pretest-Posstest, Nonequivalent Control Group Design

Table 1. The Results of Normality Test for the Agrobusiness Knowledge, Skills and Self-

Confidence by means of Kolmogorov-Smirnov Analysis Technique

\begin{tabular}{ccccccc}
\hline \multirow{2}{*}{$\begin{array}{c}\text { Training and Education } \\
\text { Pattern }\end{array}$} & \multirow{2}{*}{ Dependent Variables } & \multicolumn{2}{c}{ Pre-test } & \multicolumn{2}{c}{ Post-test } & \multirow{2}{*}{ Note } \\
\cline { 3 - 6 } & & Z K-S & $\mathrm{p}$ & $\mathrm{Z}$ K-S & $\mathrm{p}$ & \\
\hline \multirow{3}{*}{ Regular } & Knowledge & 0.856 & 0.457 & 0.913 & 0.375 & Normal \\
& Skills & 0.622 & 0.834 & 0.878 & 0.424 & Normal \\
& Self-Confidence & 0.576 & 0.894 & 0.745 & 0.635 & Normal \\
& Knowledge & 0.700 & 0.712 & 0.709 & 0.695 & Normal \\
Mentoring & Skills & 0.663 & 0.772 & 0.721 & 0.676 & Normal \\
& Self-Confidence & 0.897 & 0.396 & 0.579 & 0.890 & Normal \\
& Knowledge & 0.456 & 0.985 & 0.907 & 0.383 & Normal \\
& Skills & 0.573 & 0.898 & 0.391 & 0.988 & Normal \\
Internship & Self-Confidence & 0.672 & 0.758 & 1.124 & 0.160 & Normal \\
\hline & & & & & & \\
& & & & &
\end{tabular}

Table 2. The Results of Variant Homogeneity Test for the Agrobusiness Knowledge, Skills and Self-Confidence among the Regular, the Mentoring and the Internship Patterns by

Means of Levene's Test

\begin{tabular}{cccccccc}
\hline \multicolumn{1}{c}{ Stage } & \multicolumn{2}{c}{ Knowledge } & \multicolumn{2}{c}{ Skills } & \multicolumn{2}{c}{ Self-Confidence } & \multirow{2}{*}{ Inter-Pattern Variance } \\
\cline { 1 - 6 } & $\mathrm{F}$ & $\mathrm{p}$ & $\mathrm{F}$ & $\mathrm{p}$ & $\mathrm{F}$ & $\mathrm{p}$ & \\
\hline Pre-test & 1.477 & 0.234 & 1.509 & 0.210 & 2.251 & 0.202 & Homogeneous \\
Post-test & 0.297 & 0.744 & 1.264 & 0.410 & 3.011 & 0.504 & Homogeneous \\
\hline
\end{tabular}


All of the p-values for the participants' agrobusiness knowledge, skills and self-confidence for the regular pattern, the mentoring pattern and the internship pattern both in the pre-test and in the post-test were bigger than 0.05 . Because $p>0.05$, the researcher would like to conclude that all of the groups in the variables had normal data distribution.

The variant homogeneity test was intended to identify whether the variable among the training and education patterns had been (similarly) homogenous or not. If the variants were homogenous, then the process of differentiation test by means of parametric statistical method might be performed. The results of variant homogeneity test by means fo Levene's test were as follows Table 2.

The Levene Statistic (F) value for the agrobusiness knowledge in the pre-test group was equal to 1.477 with $p=0.234$, while the Levene Statistic (F) value for the post-test group was equal to 0.297 with $\mathrm{p}=0.744$. Similarly the $p$-value for the agrobusiness self-confidence was bigger than 0.05 ( $>0.05)$. Because p-value $>0.05$, the researcher would like to conclude that both the pre-test group and the post-test group had homogenous variants among the regular, the mentoring and the internship patterns. Since the data distribution normality test had been fulfilled both in terms of data normality and in terms of variant homogeneity, the parametric statistical test, in this case the t-test and the Analysis of Variance (Anova), might be conducted.

\section{Comparison among the Training and Edu- cation Program Participants' Knowledge, Skills and Self-Confidence during the Pre- Test and the Post-Test}

The regular pattern in the training and education program within the pre-test session showed that the mean of total score for the agrobusiness knowledge was equal to 41.93 $(\mathrm{SD}=6.00)$ and the mean of total score for the agrobusiness knowledge changed into $41.00(\mathrm{SD}=5.91)$ within the pre-test session. Meanwhile, the mean of total score for the agrobusiness skills was equal to 134.10 (SD = 11.83) within the pre-test and after the regular pattern in the training and education program (the post-test) had been implemented the mean of total score for the agrobusiness increased into $136.90(\mathrm{SD}=8.95)$. Then, the mean of total score for the agrobusiness selfconfidence was equal to 165.07 (SD 7.72) within the pre-test and the mean of total score for the agrobusiness self-confidence increase into 168.07 ( $\mathrm{SD}=9.75)$ within the post-test. The percentage of changes on the mean of total score would be summarized in the following Table 3.

Table 3. The Percentage of Changes on the Mean of Total Score from the Pre-Test to the PostTest in the Regular Pattern of Training and Education

\begin{tabular}{ccccc}
\hline Variables & $\begin{array}{c}\text { Mean } \\
\text { (Pre-test) }\end{array}$ & $\begin{array}{c}\text { Mean } \\
\text { (Post-test) }\end{array}$ & Mean Difference & Percentage of change (\%) \\
\hline Agrobusiness Knowledge & 41.93 & 41.00 & -0.93 & -2.22 \\
Agrobusiness Skills & 134.10 & 136.20 & 2.10 & 1.57 \\
Agrobusiness Self-Confidence & 165.07 & 168.07 & 3.00 & 1.82 \\
\hline
\end{tabular}

Table 4. The Summary on the Results of Paired Sample t-test for the Agrobusiness Knowledge

\begin{tabular}{|c|c|c|c|c|c|c|}
\hline Variables & Stage & Mean & $\mathrm{t}$ count & $\begin{array}{c}\mathrm{t} \text { table } \\
(\alpha=5 \% ; \mathrm{df}=29)\end{array}$ & $\mathrm{p}$ & Note \\
\hline \multirow{2}{*}{ Agrobusiness Knowledge } & Pre-test & 41.93 & \multirow{2}{*}{1.003} & \multirow{2}{*}{2.045} & \multirow{2}{*}{0.324} & \multirow{2}{*}{ Indifferent } \\
\hline & Post-test & 41.00 & & & & \\
\hline \multirow{2}{*}{ Agrobusiness Skills } & Pre-test & 134.10 & \multirow{2}{*}{-1.064} & \multirow{2}{*}{2.045} & \multirow{2}{*}{0.296} & \multirow{2}{*}{ Indifferent } \\
\hline & Pos-ttest & 136.20 & & & & \\
\hline \multirow{2}{*}{ Agrobusiness Self-Confidence } & Pre-test & 165.07 & \multirow{2}{*}{-2.279} & \multirow{2}{*}{2.045} & \multirow{2}{*}{0.030} & \multirow{2}{*}{ Different } \\
\hline & Post-test & 168.07 & & & & \\
\hline
\end{tabular}


The paired sample t-test was conducted to the agrobusiness knowledge, skills and selfconfidence in the participants of regular pattern group in order to see the statistical significancy within each change from the pretest to the post-test. The result of paired sample t-test in the regular pattern of training and education for the agrobusiness knowledge, skills and self-confidence would be presented in the following Table 4.

The agrobusiness knowledge and the agrobusiness skills in the regular pattern of training and education did not have significant change and the insignificant change had been indicated by respective p-values, 0.324 and 0.296 , which was bigger than 0.05 . Then, the participants' self-confidence in the regular pattern of training and education had significant improvement with $\mathrm{p}=0.030$, which was smaller than 0.050 . The results of hypothesis test for the mentoring pattern of training and education were as follows: the mean of total score for the agrobusiness knowledge was equal to $41.90(\mathrm{SD}=4.71)$ within the pre-test and the mean of total score for the agrobusiness knowledge was equal to $43.73(\mathrm{SD}=$
4.94) within the post-test. Then, the mean of total score for the agrobusiness skills was equal to $145.90(\mathrm{SD}=21.87)$ within the pretest and the mean of total score for the agrobusiness skills was equal to 150.47 (SD = 17.42) after the implementation of mentoring pattern (the post-test). Last but not the least, the mean of total score for the agrobusiness self-confidence was equal to 171.21 ( $\mathrm{SD}=$ 13.28) within the pre-test and the mean of total score for the agrobusiness self-confidence was equal to $175.90(\mathrm{SD}=13.01)$ after the implementation of mentoring pattern (the post-test). The percentage of the changes on the mean of total score was summarized in the following Table 5 .

The paired sample t-test was conducted to the agrobusiness knowledge, skills and selfconfidence for the participants of mentoring pattern group in order to find the statitical significance for each change from the pre-test to the post-test. The results of paired sample ttest in the mentoring pattern group for the agrobusiness knowledge, skills and self-confidence were summarized in the following Table 6.

Table 5. The Percentage of Changes on the Mean of Total Score from the Pre-Test to the PostTest in the Mentoring Pattern of Training and Education

\begin{tabular}{crrcc}
\hline Variables & $\begin{array}{c}\text { Mean } \\
\text { (Pre-test) }\end{array}$ & $\begin{array}{c}\text { Mean } \\
\text { (Post-test) }\end{array}$ & $\begin{array}{c}\text { Mean } \\
\text { Difference }\end{array}$ & $\begin{array}{c}\text { Percentage of Difference } \\
(\%)\end{array}$ \\
\hline Agrobusiness Knowledge & 41.90 & 43.73 & 1.83 & 4.37 \\
Agrobusiness Skills & 145.90 & 150.47 & 4.57 & 3.13 \\
Agrobusiness Self-Confidence & 171.27 & 175.90 & 4.63 & 2.70 \\
\hline
\end{tabular}

Table 6. The Summary on the Results of Paired Sample t-test for the Agrobusiness Knowledge, the Agrobusiness Skills and the Agrobusiness Self-Confidence in the Mentoring Pattern of Training and Education

\begin{tabular}{|c|c|c|c|c|c|c|}
\hline Variables & Stage & Mean & $\mathrm{t}$ count & $\begin{array}{c}\mathrm{t} \text { table } \\
(\alpha=5 \% ; \mathrm{df}=29)\end{array}$ & $\mathrm{p}$ & Note \\
\hline \multirow{2}{*}{$\begin{array}{l}\text { Agrobusiness } \\
\text { Knowledge }\end{array}$} & Pre-test & 41,90 & \multirow{2}{*}{-1.374} & \multirow{2}{*}{2.045} & \multirow{2}{*}{0.180} & \multirow{2}{*}{ Indifferent } \\
\hline & Post-test & 43,73 & & & & \\
\hline \multirow{2}{*}{ Agrobusiness Skills } & Pre-test & 145,90 & \multirow{2}{*}{-1.256} & \multirow{2}{*}{2.045} & \multirow{2}{*}{0.219} & \multirow{2}{*}{ Indifferent } \\
\hline & Post-test & 150,47 & & & & \\
\hline \multirow{2}{*}{$\begin{array}{l}\text { Agrobusiness Self- } \\
\text { Confidence }\end{array}$} & Pre-test & 171,27 & \multirow{2}{*}{-2.410} & \multirow{2}{*}{2.045} & \multirow{2}{*}{0.023} & \multirow{2}{*}{ Different } \\
\hline & Post-test & 175,90 & & & & \\
\hline
\end{tabular}


The agrobusiness knowledge and the agrobusiness skills in the mentoring pattern did not have significant change and the insignificant change had been indicated by the respective p-values, namely 0.180 and 0.219 , which were bigger than 0.05 . The participants' self-confidence after the implementation of mentoring pattern had significant improvement with $\mathrm{p}$ value that was equal to 0.023 , which was smaller than 0.050 . The mentoring pattern of training and education in the pre-test session showed that the mean of total score for the agrobusiness knowledge was equal to $44.27(\mathrm{SD}=6.50)$ and the mean of total score for the agrobusiness knowledge improved into $44.53(\mathrm{SD}=5.84)$ within the post-test session. Then, the mean of total score for the agrobusiness skills was equal to $141.73(\mathrm{SD}=19.09)$ within the pre-test and the mean of total score improved into 155.10 $(\mathrm{SD}=14.94)$ after the implementation of mentoring pattern (the post-test). Last but not the least, the mean of total score for the agrobusiness self-confidence was equal to 167.80 (SD = 10.85) within the pre-test and the mean of total score improved into 180.80 $(\mathrm{SD}=12.61)$ after the implementation of mentoring pattern. The percentage of changes on the mean of total score was as following Table 7.

The paired sample t-test was conducted to the agrobusiness knowledge, skills and selfconfidence for the participants of internship pattern group in order to see the significance on each change from the pre-test to the posttest. The results of paired sample t-test in the internship pattern of training and education fo the agrobusiness knowledge, skills and selfconfidence would be presented in the following Table 8.

The agrobusiness knowledge in the internship pattern of training and education did not have significant change and the insignificant change had been indicated by the $\mathrm{p}$ value that was equal to 0.777 , which had been bigger than 0.050. Meanwhile, the training and education participants' agrobusiness skills and self-confidence had significant increase with the respective p-values, namely 0.000 and 0.000 , which was smaller than 0.050 , after the implementation of mentoring pattern.

\section{Comparison on the Participants' Agrobusiness Knowledge, Skills and Self- Confidence Among the Training and Education Patterns}

In the pre-test session, the researcher would like to expect that there would not be any significant differences on the three training and education patterns because each pattern had not been under any treatment. The result test by means of variance analysis showed that the F-value for the agrobusiness knowledge during the pre-test session had been equal to 1.650 with $p=0.198$. because $p$ $>0.050$, the researcher might conclude that there had not been any significant differences in the agrobusiness knowledge among the regular, mentoring and internship training and education pattern.

Then, the F-value for the agrobusiness skills in the pre-test session was equal to 3.281 with $p=0.042$. Because $p<0.050$, there researcher might conclude that there had been significant difference in the agrobusiness skills among the regular, mentoring and internship training and education pattern during the pre-test session.

Next, the results of variance analysis for the self-confidence in the pre-test session showed that the F-value had been equal to 2.457 with $p=0.092$. Because $p<0.050$, the researcher might conclude that there had not been any actual difference in the self-confidence among the regular, mentoring and internship within the pre-test session. In overall, the test results within the pre-test session for all of the variables (the agrobusiness knowledge, the agrobusiness skills and the agrobusiness self-confidence) were be summarized in the following Tabel 9.

Table 7. The Percentage of Changes from the Pre-Test to the Post-Test

\begin{tabular}{ccccc}
\hline Variables & $\begin{array}{c}\text { Mean } \\
\text { (Pre-test) }\end{array}$ & $\begin{array}{c}\text { Mean } \\
\text { (Post-test) }\end{array}$ & Mean Difference & Percentage of Changes (\%) \\
\hline Agrobusiness Knowledge & 44.27 & 44.53 & 0.26 & 0.59 \\
Agrobusiness Skills & 141.73 & 155.10 & 13.37 & 9.43 \\
Agrobusiness Self-Confidence & 167.80 & 180.80 & 13.00 & 7.75 \\
\hline
\end{tabular}


Table 8. The Results of Paired Sample t-test for the Agrobusiness Knowledge, Skills and SelfConfidence in the Internship Pattern of Training and Education

\begin{tabular}{|c|c|c|c|c|c|c|}
\hline Variables & Stage & Mean & $\mathrm{t}$ count & $\begin{array}{c}\mathrm{t} \text { table } \\
(\alpha=5 \% ; \mathrm{df}=29)\end{array}$ & $\mathrm{p}$ & Note \\
\hline Agrobusiness Knowledge & & & -0.285 & 2.045 & 0.777 & Indifferent \\
\hline Agrobusiness Skills & $\begin{array}{l}\text { Pre-test } \\
\text { Post-test }\end{array}$ & $\begin{array}{l}145.90 \\
150.47\end{array}$ & -4.974 & 2.045 & 0.000 & Indifferent \\
\hline Agrobusiness Self-Confidence & $\begin{array}{l}\text { Pre-test } \\
\text { Post-test }\end{array}$ & $\begin{array}{l}171.27 \\
175.90\end{array}$ & -4.944 & 2.045 & 0.000 & Very Different \\
\hline
\end{tabular}

Table 9. Results of Variance Analysis on the Pre-Test Session for the Agrobusiness Knowledge, the Agrobusiness Skills and the Agrobusiness Self-Confidence

\begin{tabular}{|c|c|c|c|c|c|c|}
\hline Variables & $\begin{array}{c}\text { Training and Education } \\
\text { Pattern }\end{array}$ & Mean & $\begin{array}{c}\mathrm{F} \\
\text { count }\end{array}$ & $\begin{array}{l}F \text { table } \\
(\mathrm{df} 1=2 ; \\
\mathrm{df} 2=87)\end{array}$ & $\mathrm{p}$ & Note \\
\hline \multirow{4}{*}{$\begin{array}{l}\text { Agrobusiness } \\
\text { Knowledge }\end{array}$} & Regular & 41.93 & \multirow{4}{*}{1.650} & \multirow{4}{*}{3.101} & \multirow{3}{*}{0.198} & \multirow{3}{*}{ Indifferent } \\
\hline & Mentoring & 41.90 & & & & \\
\hline & Internship & 44.27 & & & & \\
\hline & Regular & 134.10 & & & & \\
\hline \multirow[t]{2}{*}{ Agrobusiness Skills } & Mentoring & 145.90 & \multirow[t]{2}{*}{3.281} & \multirow[t]{2}{*}{3.101} & \multirow[t]{2}{*}{0.042} & \multirow[t]{2}{*}{ Different } \\
\hline & Internship & 141.73 & & & & \\
\hline \multirow{3}{*}{$\begin{array}{l}\text { Agrobusiness Self- } \\
\text { Confidence }\end{array}$} & Regular & 165.07 & \multirow{3}{*}{2.457} & \multirow{3}{*}{3.101} & \multirow{3}{*}{0.092} & \multirow{3}{*}{ Indifferent } \\
\hline & Mentoring & 171.27 & & & & \\
\hline & Internship & 167.80 & & & & \\
\hline
\end{tabular}

Table 10. Results of Variance Analysis on the Post-Test Session for the Agrobusiness Knowledge, the Agrobusiness Skills and the Agrobusiness Self-Confidence

\begin{tabular}{|c|c|c|c|c|c|c|}
\hline Variables & $\begin{array}{c}\text { Training and Education } \\
\text { Pattern }\end{array}$ & Mean & $\begin{array}{c}\mathrm{F} \\
\text { count }\end{array}$ & $\begin{array}{l}\mathrm{F} \text { table } \\
(\mathrm{df} 1=2 ; \\
\mathrm{df} 2=87)\end{array}$ & $\mathrm{p}$ & Note \\
\hline \multirow{4}{*}{$\begin{array}{l}\text { Agrobusiness } \\
\text { Knowledge }\end{array}$} & Regular & 41.93 & \multirow{4}{*}{3.307} & \multirow{4}{*}{3.101} & \multirow{4}{*}{0.04} & \multirow{4}{*}{ Different } \\
\hline & Mentoring & 41.90 & & & & \\
\hline & Internship & 44.27 & & & & \\
\hline & Regular & 134.10 & & & & \\
\hline \multirow[t]{2}{*}{ Agrobusiness Skills } & Mentoring & 145.90 & \multirow[t]{2}{*}{14.397} & \multirow[t]{2}{*}{3.101} & \multirow[t]{2}{*}{0.00} & \multirow[t]{2}{*}{ Indifferent } \\
\hline & Internship & 141.73 & & & & \\
\hline $\begin{array}{l}\text { Agrobusiness Self- } \\
\text { Confidence }\end{array}$ & Regular & 165.07 & 8.777 & 3.101 & 0.00 & Indifferent \\
\hline
\end{tabular}

On the other hand, the test results by means of variance analysis showed that the Fvalue for the agrobusiness knowledge within the post-test session had been equal to 3.307 with $\mathrm{p}=0.041$. Because $\mathrm{p}<0.050$, the researcher might conclude that there had been actual difference on the agrobusiness knowledge among the regular, mentoring and in- ternship training and education pattern within the post-test session.

Then, the F-value for the agrobusiness skills in the post-test session was equal to 14.397 with $\mathrm{p}=0.000$. Because $\mathrm{p}<0.050$ (or even $<0.010$ ), the researcher might conclude that there had been very actual difference on the agrobusiness skills among the regular, 
mentoring and internship training and education pattern.

Last but not the least, the results of variance analysis for the agrobusiness selfconfidence in the post-test session showed that the F-value had been equal to 8.777 with $p=0.000$. Because $p<0.050$ (even $<0.010$ ), the researcher might conclude that there had been very actual difference on the agrobusiness self-confidence among the regular, mentoring and internship training and education pattern within the post-test session. In overall, the test results within the post-test session for all of the variables (the agrobusiness knowledge, the agrobusiness skills and the agrobusiness self-confidence) were summarized in the following Table 10:

Comparison on the Participants'

Agrobusiness Knowledge, Skills and SelfConfidence without Considering the Training and Education Patterns

In this section, the researcher would like to identify the influence of pre-test and post-test treatment without any consideration toward the training and education pattern. In addition, the researcher would like to identify as well the influence of interaction between the pretest and the post-test by means of the implemented training and education patterns and the identification would be performed by using the multivariate analysis of variance. The results of analysis would be used for identifying the influence of pre-test and post- test treatment as well as the impact of interaction between the pre-test-post-test treatment and the regular, mentoring and internship training and education patterns. The test results were presented in the following Table 11.

The F-value was equal to 0.387 with significance $p=0.536$. Because $p>0.050$, the researcher would like to conclude that there had not been any significant difference in the score of agrobusiness knowledge between the pre-test session and the post-test session without any consideration toward the training and education pattern. In other words, the provision of training and education activities did not provide any actual change on the agrobusiness knowledge.

The impact of interaction between the pre-test-post-test treatment and the training and education patterns toward the agrobusiness knowledge was shown by the second lines of the Table 11. The second line showed that the F-value had been equal to 1.641 with significance $p=0.200$. Because $p>0.050$, the researcher would like to conclude that the interaction between the pre-test-post-test treatment and the training and education patterns did not provide any actual impact in terms of difference on the score of agrobusiness knowledge. The graphical representation between the pre-test treatment and the post-test treatment for the regular, mentoring and internship training and education pattern was illustrated in the following Figure 2.

Table 11. Results of Multivariate Analysis of Variance (General Linear Model) on the Agrobusiness Knowledge among the Regular, Mentoring and Internship Training and Education Pattern

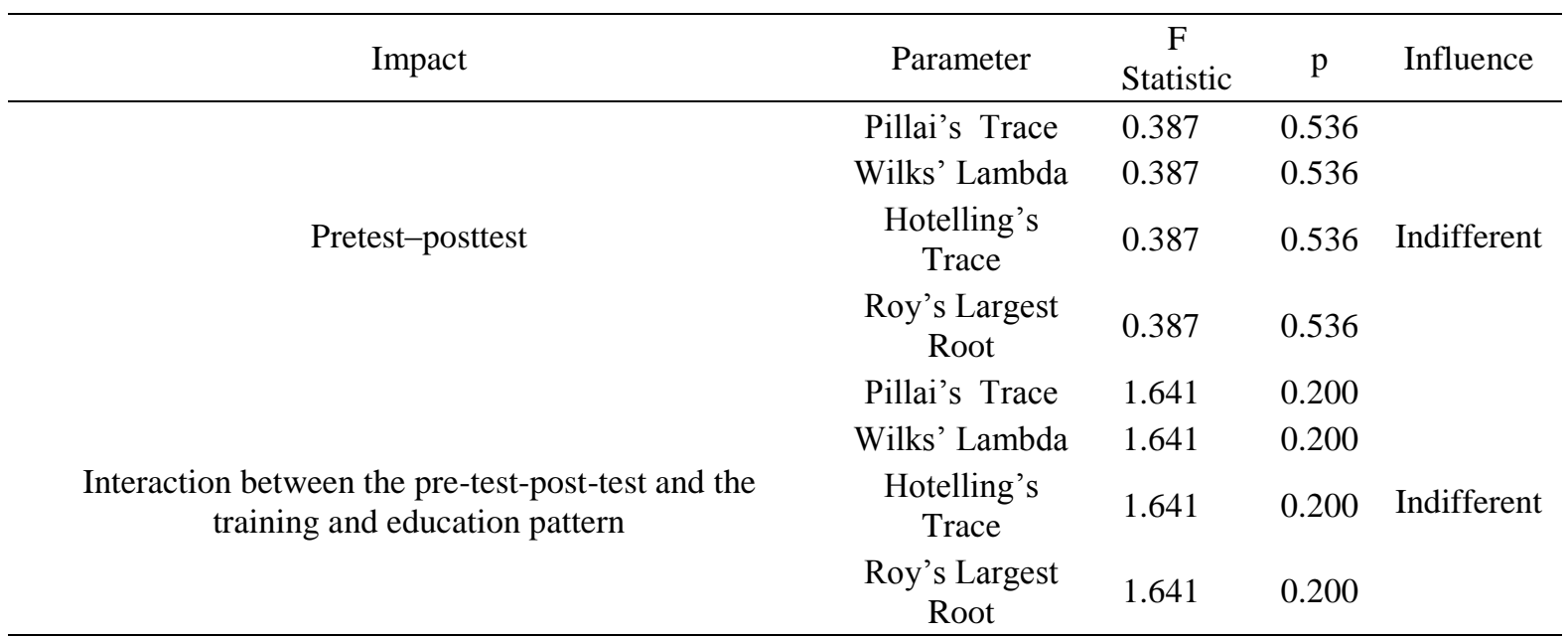




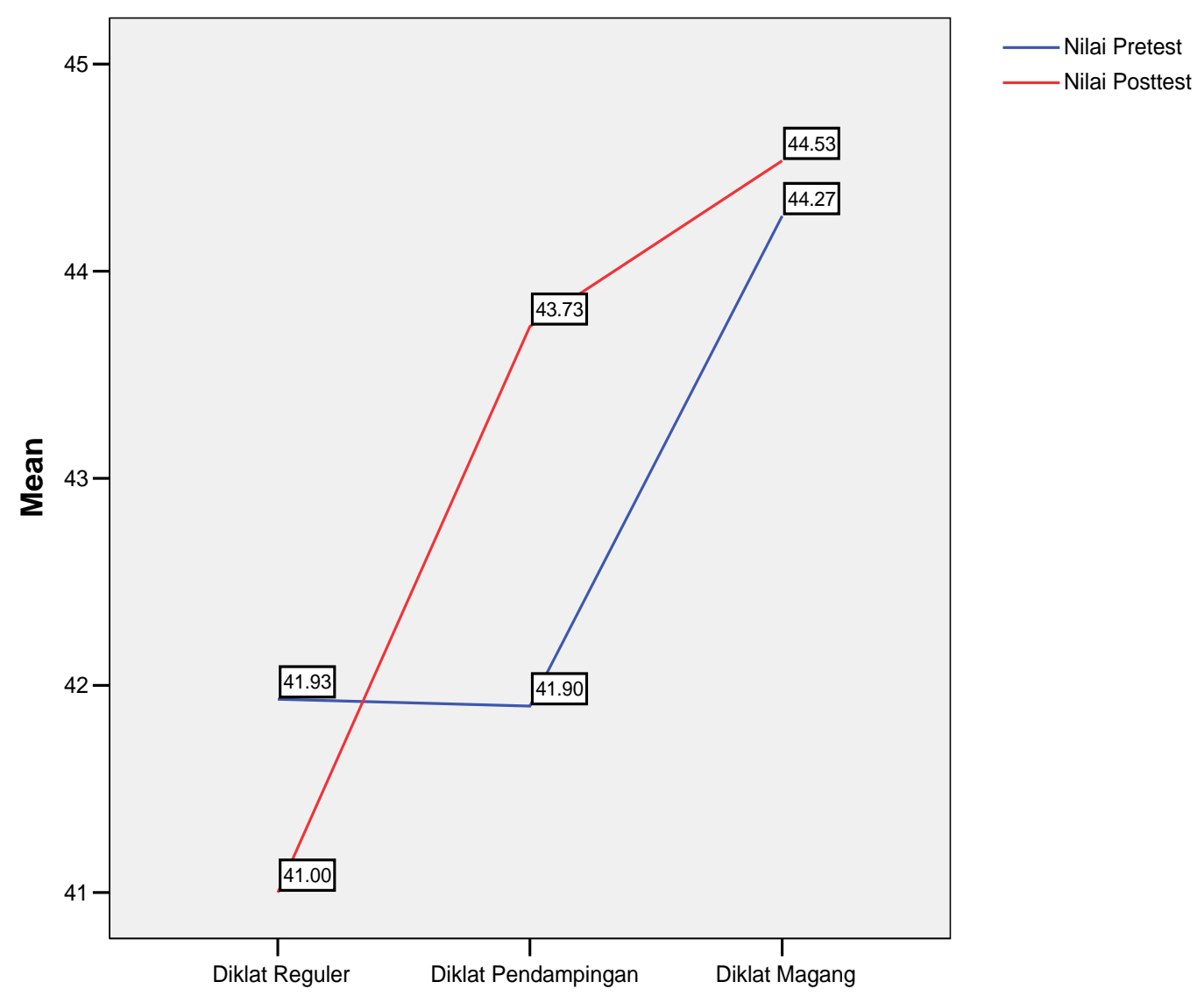

Figure 2. The Diagram of Mean Comparison for the Agrobusiness Knowledge, the Agrobusiness Skills and the Agrobusiness Self-Confidence in the Pre-test and the Post-test Session

In a simple manner, it had been found that in terms of agrobusiness knowledge, the mentoring training and education pattern showed the biggest percentage of change from the pre-test session to the post-test session score in comparison to the two other training and education patterns. The percentage was $4.37 \%$ and the mean score increased from 41.90 into 43.73 . Then, the internship training and education pattern showed the second biggest percentage of change from the pre-test session to the post-test session score. The percentage was $0.59 \%$ and the mean score increased from 44.27 into 44.53. Meanwhile, in the regular training and education pattern, the participants' score of agrobusiness knowledge decreased for about $2.22 \%$ from 41.93 into 41.00 .

The test results by means of Multivariate Analysis of Variance (General Linear Model) with the repeated measures option and the analytical tools in the form of Pillai Trace, Wilks' Lambda, Hotelling's Trace and
Roy's Largest Root toward the agrobusiness knowledge showed that there had not been any significant difference (the F-value was equal to 0,387 with significance $p=0.536$ ) between the pre-test stage and post-test stage without considering the training and education pattern that had been implemented. In other words, the three training and education patterns had similar performance in improving the agrobusiness knowledge. The test results on the interacton impact between the pretestposttest treatment and the training and education patterns toward the agrobusiness knowledge did not show any actual influence (F-count was equal to 1.641 with significance $p=0.200$ ). In othe words, the interaction between the pretest-posttest treatment and the training and education pattern did not provide any actual impact of difference on the score of agrobusiness knowledge.

In the agrobusiness skills, the mentoring training and education pattern proved to have the biggest percentage of change namely 
$9.43 \%$. The mean score of the agrobusiness skills in the mentoring training and education pattern increased from 141.73 (pre-test) into 155.10 (post-test). Then, the coaching training and education pattern had the second biggest percentage of change namely $3.13 \%$. The mean score of agrobusiness skills in the coaching training and education pattern increased from 145.90 into 150.47. Last but not the least, the regular training and education pattern showed the smallest percentage of change in the agrobusiness skills namely $1.57 \%$. The mean score of the agrobusiness skillls in the regular training and education pattern increased from 134.10 (pre-test) into 136.20 (post-test).

The results of paired sample t-test in the mentoring training and education pattern showed very significant difference for the agrobusiness skills $(\mathrm{t}$ count $=-4.974, \mathrm{p}=$ 0.000 ) and for the agrobusiness self-confidence $(\mathrm{t}$ count $=-4.944, \mathrm{p}=0.000)$. The results of $t$ test did not show any actual difference in terms of agrobusiness knowledge. The results of differential test between the pretest and the posttest treatment on the other hand showed very significant difference ( $F$ count was equal to 16.492 with significance $p$ $=0.000)$. There had been significant difference in the score of agrobusiness skills between the pre-test session and the post-test session. In other words, the training and education program showed very significant change for the agrobusiness skills. The test results for the interaction impact between the pretest-posttest treatment and the training and education patterns toward the agrobusiness skills showed very significant difference $(\mathrm{F}$ count was equal o 4.324 with $\mathrm{p}=$ 0.016 ). The interaction between the pretestposttest treatment and the training and education patterns provided significant impact of difference in the score of agrobusiness skills. The finding implied that the selected training and education pattern had significant influence toward the agrobusiness skills in creating changes between the pre-test and the post-test session.

In the agrobusiness self-confidence, the percentage of change was similar to that of agrobusiness skills and the internship training and education pattern attained the biggest percentage of change followed by the mentoring and the regular training and education pattern respectively. The internship training and education pattern proved to show the biggest percentage of change namely $7.75 \%$. The mean score of agrobusiness self-confidence in the internship training and education pattern increased from 167.80 (pre-test) into 180.80 (post-test). Then, the mentoring training and education pattern showed the second biggest percentage of stage namely $2.70 \%$. The mean score of agrobusiness self-confidence in the mentoring training and education pattern increased from 171.27 into 175.90. Meanwhile, the regular training and education pattern showed the smallest percentage of change namely $1.82 \%$. The mean score of the agrobusiness self-confidence in the regular training and education pattern increased from 165.07 (pre-test) into 168.07 (post-test).

The test of difference by means of paired sample t-test showed that the regular training and education pattern had the significant difference on the agrobusiness selfconfidence and the significant difference was indicated by the $\mathrm{t}$ count score that had been equal to $-2.279(\mathrm{p}=0.030)$. On the other hand, for the agrobusiness knowledge and the agrobusiness skills there had not been any actual difference.

The paired sample t-test for the mentoring training and education pattern showed actual difference on the agrobusiness self-confidence and the actual difference had been indicated by the t-count value that had been equal to $-2.410(\mathrm{p}=0.023)$. The results of paired sample t-test did not show actual difference for the agrobusiness knowledge and the agrobusiness skills. The results on the test of difference for the pre-test and the posttest treatment showed very significant difference on the agrobusiness self-confidence (Fcount value was equal to 34.490 with $\mathrm{p}=$ 0.000 ) without considering the implemented training and education pattern. In other words, the training and education programs provided very significant changes on the agrobusiness self-confidence. The results on the test of interaction impact between the pretest-posttest treatment and the training and education patterns toward the agrobusiness self-confidence showed very significant impact on the agrobusiness self-confidence (F-count value was equal to 6.904 with significance $\mathrm{p}=$ 0.002). The interaction between the pretestposttest treatment and the training and edu- 
cation patterns provided very significant impact of difference on the score of agrobusiness self-confidence. In other words, the selected training and education pattern had significant influence toward the self-confidence in creating differences between the pre-test and the post-test treatment.

The results of a study about the effectiveness of a training and education program might be identified by conducting an evaluation based on the context, the input, the process and the output as having been used in measuring the effectiveness of schooling programs and the method of measuring the effectiveness of schooling programs had been introduced by Scheerens (1990, p. 73). The implementation of a training and education program should be the results of cooperation from all components in the training and education institution. Integrally, the system of training and education might be illustrated in a training and education fundamental function model as following Figure 3 .

The figure or the diagram above described the contextual factors, the input, the process and the output that occured in the implementation of a training and education program both in the training and education level itself and in the classroom level. The evaluation toward the training and education context in relation to the objectives that had been achieved should be conducted after the participants had finished the training and education programs. In the case of agrobusiness technical training and education for the field farming extension officers, the objective that should be achieved was that after attending the training and education program the participants were expected to expand their knowledge, skills and selfconfidence in the domain of agrobusiness entrepreneurship. Then, the second objective was that the training and education participants should be able to implement the farming extension activities to the farmers by implementing the agrobusiness principles. In general, for the first objective the training and education participants had been able to increase their knowledge for about $1.00 \%$, their skills for about $4.71 \%$ and their self-confidence for about $4.01 \%$. The improvement on the knowledge, the skills and the self-confidence was relatively low in comparison to the fund that had been spent in accordance with the Minister of Finance Regulation Number 115/PMK.2/2015 regarding the Standard of Expenditure (Kementerian Keuangan, 2014). The regulation stated that the unit of expenditure for the agrobusiness technical training and education should be equal to $\mathrm{Rp}$ $3,599,666.00 /$ person.

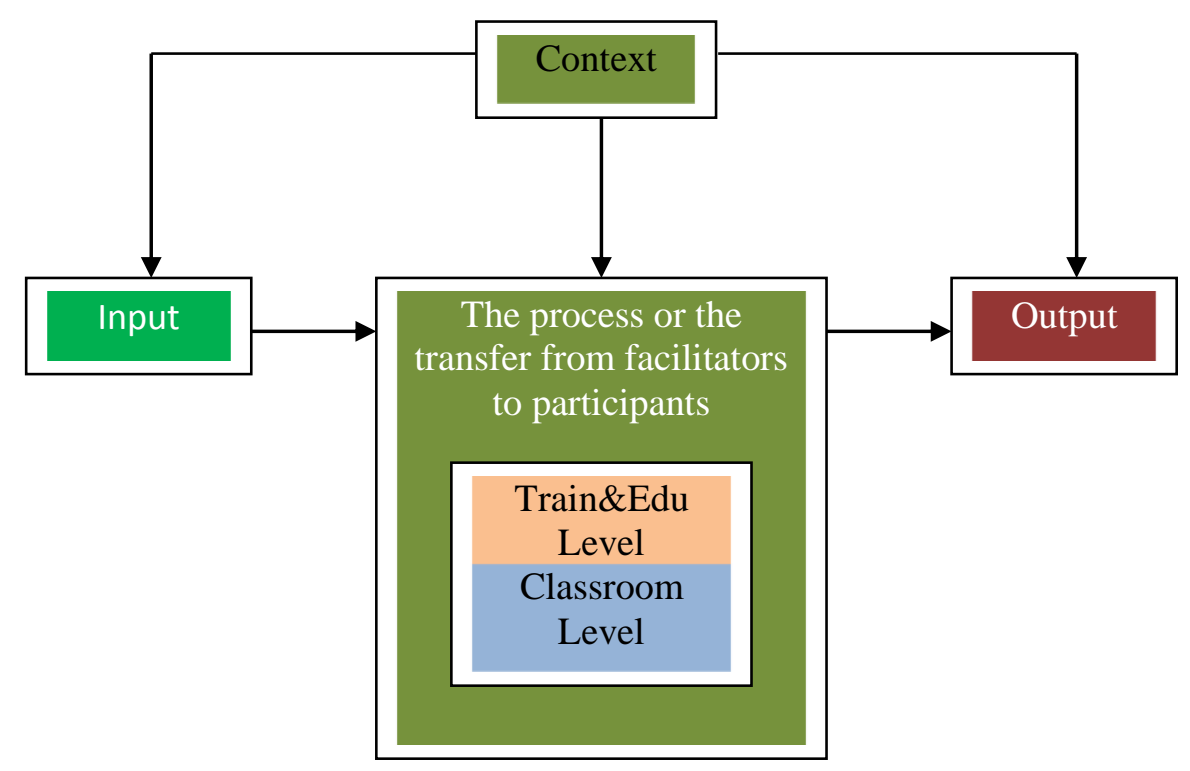

Figure 3. The Training and Education Fundamental Function Model 


\section{CONCLUSIONS}

The implementation of internship training and education pattern has been more effective in improving the participants' skills and self-confidence in comparison to the regular and the mentoring training and education pattern. In general, the improvement was $8.34 \%$ for the participants' skills and $8.02 \%$ for the participants' self-confidence. The regular training and education pattern only shows actual difference on the field farming extension officers' self-confidence $(\mathrm{t}$ count $=-2.279 ; \mathrm{p}=0.030$ ). Meanwhile, the mentoring training and education pattern only shows significant difference for the field farming extension officers' self-confidence $(\mathrm{t}$ count $=-2.410 ; p=0.023$ ). On the other hand, the internship training and education pattern shows very significant difference for the field farming extension officers' agrobusiness skills $(\mathrm{t}$ count $=-4.974 ; \mathrm{p}=0.000)$ and self-confidence ( $\mathrm{t}$ count $=4.944 ; \mathrm{p}=0.000)$.

For the level of participants' agrobusiness knowledge, the biggest percentage of change has been attainedby the mentoring training and education pattern followed by the regular and the internship training and education pattern. Furthermore, for the level of participants' agrobusiness skills the biggest percentage of change has been attained by the internship training and education pattern followed by the mentoring and the regular training and education program. Last but not the least, for the level of participants' self-confidence the biggest percentage of change has been attained by the internship training and education pattern followed by the mentoring and the regular training and education program.

The pretest-posttest treatment (without considering the training and education patterns) provides a very significant difference for the agrobusiness skills $(\mathrm{F}$ count $=16.492$; $\mathrm{p}=0.000)$ and the self-confidence $(\mathrm{F}$ count $=$ $34.490 ; p=0.000)$. However, the difference is not significant for the agrobusiness knowledge $(\mathrm{F}$ count $=0.387 ; \mathrm{p}=0.536)$.

The regular training and education pattern shows an actual difference between the pre-test and the post-test session for the field farming extension officers' agrobusiness self-confidence and does not show a significant difference for the field farming exten- sion officers' agrobusiness knowledge and skills. Then, the mentoring training and education pattern shows an actual difference for the field farming extension officers' agrobusiness self-confidence and does not show an actual difference for the field farming extension officers' agrobusiness knowledge and skills. On the other hand, the internship training and education pattern shows a very significant difference for the field farming extension officers' agrobusiness skills and self-confidence but does not show an actual difference for the field farming extension officers' agrobusiness knowledge.

\section{Suggestions}

In order to improve the field farming extension officers' agrobusiness knowledge, skills and self-confidence, the researcher would like to recommend the use of the mentoring or the internship training and education pattern. The reason is that the mentoring or the internship training and education pattern might provide a significant contribution.

The regular training and education pattern might be implemented continously by developing the training and education curriculum. In addition, the practical activities should be conducted in addition to the theoretical explanations.

The agrobusines technical training and education is important to implement continously in order to improve the Field Farming Extension Officers' performance. The improvement of their performance might bring about a better prosperity for the farmers and their families by means of agrobusiness development.

Last but not the least, for the future studies the researcher would like to suggest that the future researchers should review the other variables that might influence the results of training and education programs such as participants' motivation, educational background and age.

\section{REFERENCES}

Badan Pendidikan dan Latihan Pertanian. (1993). Agribisnis seri 1. Jakarta: Departemen Pertanian.

Kementerian Keuangan. (2014). Peraturan Menteri Keuangan No.115/PMK.2/2015 
tentang standar biaya keluaran. Jakarta: Kementerian Pertanian.

Kementerian Pertanian. (2014). Renstra 2015 - 2019 Kementerian Pertanian RI.

Jakarta: Kementerian Pertanian.

Scheerens, J. (1990). School Effectiveness

Research and the Development of

Process Indicators of School
Functioning. School Effectiveness and School Improvement, 1(1), 61-80. https://doi.org/10.1080/09243459000101 06

Wiersma, W. (1995). Research methods in education: An introduction.

Massachusetts: A Simon and Schuster Company. 